\title{
Influence of Engagement, Work-Environment, Motivation, Organizational Learning, and Supportive Culture on Job Satisfaction
}

Muhammad Majid (Corresponding author)

Faculty of Business and Management, Universiti Teknologi Mara (UiTM), Cawangan Johor, Kampus Segamat E-mail: muhdmajid@uitm.edu.my

Mohamad Faizal Ramli

Universiti Teknologi Mara (UiTM), Cawangan Johor, Kampus Segamat

Basri Badyalina

Universiti Teknologi Mara (UiTM), Cawangan Johor, Kampus Segamat

\author{
Azreen Roslan \\ Universiti Teknologi Mara (UiTM), \\ Cawangan Selangor, Kampus Puncak Alam, Malaysia
}

Azreen Jihan Che Mohd Hashim

Universiti Sains Islam Malaysia (USIM)

Received: Oct. 3, 2020 Accepted: Nov. 2, 2020 Online published: Nov. 4, 2020

doi:10.5296/ijhrs.v10i4.17822 URL: https://doi.org/10.5296/ijhrs.v10i4.17822 


\section{I Macrothink}

International Journal of Human Resource Studies

ISSN 2162-3058

2020, Vol. 10, No. 4

\section{Abstract}

This paper intends to investigate the role of engagement, motivation, work environment, supportive culture, and organizational learning on job satisfaction. Responses were collected from 169 employees in Malaysian higher education sector. Further, the data obtained were analysed by using Statistical Package for the Social Sciences (SPSS). The results indicated that there are positive and significant relationships between engagement, supportive culture, motivation, and work environment on job satisfaction among employees of Malaysian higher education sector. However, organizational learning is not a significant towards job satisfaction. In future research, employees from private universities and public universities can be studied as comparison. By conducting these comparisons, it will help in creating plans to narrow down the gaps between these two sectors. In addition, the results will help to enhance the rising literature on job satisfaction from Asian context as this study was based on Malaysian samples. Data from employees working in different higher education institutions was utilized for this study to ensure the unbiased responses. Therefore, this study contributes to the literature concerning job satisfaction among employees, and the results of this study provide significant evidence on the influence of engagement, motivation, work-environment, organizational learning and supportive culture on job satisfaction in Malaysian higher education sector.

Keywords: Malaysia, engagement, motivation, work environment, organizational learning, supportive culture, job satisfaction, higher education

\section{Introduction}

Basically, job satisfaction has been studied in the recent years and the past few decades (Tahir, Hussein \& Rahim 2020; Zahari, Salleh, Azlan, Baharuddin, Baniamin 2020; Hanaysha, 2016; Castaneda \& Scanlan, 2014; Mavridis, 2014). In general, job satisfaction can be described as the opinion of individual towards their work and job experience (Laschinger, Zhu, \& Read, 2016). In addition, Tahir et al., (2020) defines job satisfaction as the individual's emotional condition which draws from his or her experiences particularly work environment.

As reported by the Malaysian Reserve (2017), JobStreet.com has conducted a research on job satisfaction in Malaysia. Surprisingly, the findings of the research revealed that $78 \%$ of respondents were disappointed and unhappy with their current jobs. Further, JobStreet.com mentioned that the primary reason many felt unhappy at work was because of the scope of work. The study was participated by 1,145 employees $(62 \%$ were from the middle management level).

Fauziah et al (2009) conducted a research on job satisfaction level (among academic staff in Malaysia) and the researchers stated that effective education systems were relying on a few factors such as involvement, effort, and the general academic staff professionalism. The researchers further added that job satisfaction among academic staff are essential towards the success of the academic institutions. A progressive university environment could help towards an increased in job satisfaction among academic staff. 
A recent research by (Hee, Ong, Ping, Kowang, \& Fei, 2019), stressed that employee satisfaction is significant to any organisations especially to the higher learning institutions. Thus, factors that can influence job satisfaction need to be given further attention, this will help to increase a high quality of education and most importantly students' learning outcomes can be achieved positively.

Moreover, the attention given towards researching job satisfaction has shown the importance of this topic. Thus, to be successful, organizations need to make sure that the workers are satisfied with their jobs (Hanaysha, 2016). As discussed above, job satisfaction is an important factor applied to evaluate organizational effectiveness (Khan, Anjam, Faiz \& Khan, 2020). Additionally, employees who are satisfied are more likely to be committed and productive. It is essential to understand that somehow the workforce play a part as an important role to increase the organizational performance.

Hence it is vital to make sure that employees have the skills that meet organizational needs. Furthermore, human capital leads to organizational success and organizations need to maximize human resources competencies strategically to boost employees' performance (Ngwenya \& Pelser, 2020). According to Zahari et al., (2020) the successfulness of an organisation has been associated to attain job satisfaction at a greater level. In addition, to maintain a long-term performance, job satisfaction among workers should be emphasised (Arnold \& Silvester, 2005).

Job satisfaction among employees and workforce is a crucial element of organizational success especially in managing the human resources of the organization (Zahari et al., 2020; Gitoho, 2015). There are a few factors that can affect job satisfaction for instance, Jolodar and Jolodar (2012) proved that job satisfaction was related with employee productivity and human resources development. Based on a study conducted by (Lo \& Ramayah, 2011) there are several elements that linked to job satisfaction. One of the elements is organizational learning. Maarefi et al. (2020) found that it is vital to increase organizational learning to increase job satisfaction among employees.

In addition, a study conducted by Hanaysha (2016) also found that organizational learning has significantly affect job satisfaction. Thus, organizational learning signifies the capability of an organization in increasing the skills and knowledge of its workers to safeguard better productivity and efficiency at workplace.

Fascinatingly, employee engagement is another element that has been researched to influence job satisfaction. Nowack (2011) defined work engagement as an important role in influencing job satisfaction and retention. The study on employee engagement has emerged reasonably in the recent literature. A recent study by Ngwenya and Pelser (2020) in the manufacturing sector in Zimbabwe has shown that employee engagement has significantly influenced employee performance and job satisfaction positively influenced employee engagement. Another empirical study on employee engagement and job satisfaction in China indicated that workplace has a large influence on employee engagement and job satisfaction (Rashidin, Javed \& Liu, 2020). Moreover, the needs of satisfaction have been linked to dedication of workers (Vandenabeele, 2014). In addition, the basic needs of satisfaction have been 
discovered to directly relate to dedication of employees (Vandenabeele, 2014). Thus, by examining these variables namely work engagement and job satisfaction, it will enhance the insights about the topic and will offer valuable recommendations for the management of higher learning institutions to establish the right policies and strategies.

Besides, several studies have been linked between job satisfaction and motivation (Stefurak, Morgan \& Johnson, 2020; Carvalho, Riana \& Soares, 2020; and work environment (Anasi, 2020; Badrianto \& Ekhsan, 2020; Kumar, 2020; Hanaysha, 2016). Kumar (2020) stressed that job satisfaction is impacted by the attributes of work environment. To add on, Badrianto \& Ekhsan, (2020) mentioned in their study that there are some factors that can influence the success of employee performance and this includes work environment and job satisfaction. Thus, organizations should empathize on rapid changes in the business environment and organizations need to regularly improve and upgrade the required facilities for workers (Hanaysha, 2016). This is to ensure that they can perform their tasks productively and with full satisfaction. It is important to note that, a satisfying working environment and right motivation can encourage workers to be more efficient and productive hence can lead to a higher level of satisfaction among employees.

Among the factors mentioned above, another factor that is linked to job satisfaction is culture (Verma, 2020; Meng \& Berger, 2019; Pawirosumarto, Sarjana and Gunawan, 2017;). Culture can be defined as values that are comprehended and understood, recognized, followed, and observed together by the workforce (Pawirosumarto et al., 2017). Moreover, culture uniquely belongs to the organization and that makes the difference from other organizations (Pawirosumarto et al., 2017; Marta \& Suharnomo, 2011). Thus, it is vital for organisations to establish and sustain a culture that can provide them with a solid foundation. This will help to increase employees' satisfaction and will improve their performance.

Following those arguments, there are so many factors that can influence employee satisfaction. Hence, this study focuses on the effects of organizational learning, work environment, employee motivation, employee engagement and supportive culture on job satisfaction of selected universities in Malaysia. From the review of the literature, there are limited research on examining the link between the identified elements (Hanaysha, 2016). In addition, the researcher suggested studying other variables to identify the major predictors of job satisfaction. Another research from Yeh (2013) on job satisfaction among frontline hotel employee has also recommended future research to investigate other work-related variables. The researcher also mentioned that little research attention has been done on the on-work engagement and job satisfaction, the research was conducted in the context of hotel industry.

Besides, a research by Pawirosumarto et al., (2017) on the effects of the work environment, organizational culture and job satisfaction among hotel employees has also recommended conducting similar study in the different industries. Thus, in this study, supportive culture is another variable to be studied. Determined from the gaps stated above, hence this study seeks to offer a considerable contribution and impact to the existing literature. Those five determinants work engagement, employee motivation, supportive culture, work environment, and organizational learning were selected to be discussed in this research. 


\section{Literature Review}

\subsection{Job Satisfaction}

In general, job satisfaction can be described as "an emotional or effective response to several aspects of the job" (Pawirosumarto et al., 2017; Kreitner \& Kinicki, 2008). While, based on Robbins (2003) job satisfaction is "the general attitude towards the performance of someone who shows the difference between the numbers of awards received by them and the amount they believe they should receive". In addition, according to Pawirosumarto et al., (2017) an individual will be satisfied or dissatisfied with his or her job is something personal, depending on how an individual identifies the conflict or dispute between his or her desires with the outcome or result.

Moreover, it can be assumed that job satisfaction is the positive mindset or attitude of the workers. This includes attitudes and feelings over the assessment or evaluation of a job as a sense of respect in attaining the value of work. An individual will achieve certain level of job satisfaction when the preferred limit has been accomplished, plus there are no gaps between his or her desires and the truth.

Most importantly, organizations value job satisfaction as a main priority and it can be assessed through some aspects. For example, most workers who are satisfied are more likely to be experiencing comfort and positive experience towards their job (Hanaysha, 2016). Employee job satisfaction is a factor among others that are linked to performance (Carvalho et al., 2020). Job satisfaction is also important towards the success of a company. In general, job satisfaction gives a few advantages for both workers and organisations. From the viewpoint of workers, it helps to provide comfort, happiness and workers enjoy their job. Meanwhile, from the organizational viewpoint, job satisfaction helps to produce desired outcome.

\subsection{Employee Engagement}

Employee engagement is essential to any organization. It is also a main priority for many organizations. Nowadays, one of the ways to retain workers is to have fully engaged workers.

According to Ngwenya and Pelser (2020) job satisfaction influenced engagement and employee performance. A study by Abraham (2012) on a private insurance company found that there is a relation between job satisfaction and employee engagement. Similarly, another research conducted by Vorina, Simonic and Vlasova (2017) in Slovenia's public and private sector also found that employee engagement and job satisfaction are related.

In addition, a study conducted by Kim-soon \& Manikayasagam (2017) revealed a positive relationship between employee engagement and job satisfaction. The researcher added that by providing employee the engagement chances, a company would be able to increase job satisfaction among employees. It is believed that engaged workers are more likely to be higher in job satisfaction.

Moreover, these findings were also supported by a research by (Karanika-Murray, Duncan, Pontes \& Griffiths, 2015) where there is an indirect via work-engagement and positive effect of organizational identification on job satisfaction. In addition, Yeh (2013) conducted a study 
on the relationship between work engagement and job satisfaction, the study was conducted in the hotel industry. The result also found that work engagement was positively related to job satisfaction.

Based on the discussion and to find the relationship, the following hypothesis is proposed:

H1: Employee engagement has positive effect on job satisfaction in Malaysian higher education sector.

\subsection{Employee Motivation}

In managing human resources, employee motivation at the organisation must be a serious concern. It is important to maintain and manage employee motivation. This is to ensure that they can focus on achieving organizational goals (Carvalho et al., 2020). Employees who are not motivated will not do things optimally. A research conducted by Saleem, Mahmood, Mahmood (2010) discovered that, levels of motivation on job satisfaction are positively related. The research was conducted among employees of telecommunication companies in Pakistan. Prysmakova \& Vandenabeele (2019) confirmed that employees with higher level of motivation have higher levels of job satisfaction. The data was obtained from Polish and Belgian police officers. Furthermore, a study on motivation and job satisfaction of employees in private university libraries in Nigeria found that motivation is expected to increase job satisfaction. The researcher further added that satisfied employees are productive employees, and they are willing to work and stay for the attainment of the organization (Idiegbeyan-Ose, Opeke, Aregbesola, Owolabi \& Eyiolorunshe, 2019).

Therefore, these arguments help in forming the following hypothesis:

$\mathrm{H} 2$ : Employee motivation has positive effect on job satisfaction in Malaysian higher education sector.

\subsection{Work Environment}

Work environment is where the workers do activities on daily basis. Thus, it is crucial to have conducive working environment. This is to help create a sense of security and protection and allows the workers to work optimally (Badrianto \& Ekhsan, 2020). A recent study by Kumar (2020) concluded that job characteristics of (work environment) have impacted job satisfaction whereby the data was obtained from 6041 police officers in India. Similarly, a research by Sunarsi (2019) found that the work environment has a positive and significant impact on work satisfaction. Likewise, Akinwale \& George (2020) discovered that all variables of work environment influenced job satisfaction. The researchers conducted the study on work environment and job satisfaction among nurses in hospitals in Nigeria.

Furthermore, Al-Hamdan, Manojlovich, \& Tanima (2017) concluded that the work environment was positively influenced job satisfaction. The researchers further stressed that more consideration should be given, this is to ensure to establish a positive environment and to enhance job satisfaction among nurses.

Apart from that, a study conducted by Badrianto and Ekhsan (2020) found that work environment and job satisfaction have positive and significant impact on employee performance. Based on the above discussions, the following hypothesis is proposed: 


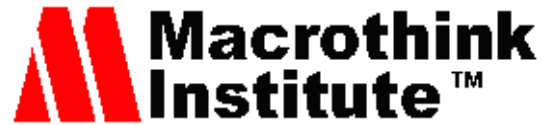

International Journal of Human Resource Studies

ISSN 2162-3058

2020, Vol. 10, No. 4

H3: Work environment has positive effect on job satisfaction in Malaysian higher education sector.

\subsection{Organizational Learning}

Organisational learning can be defined as a process (Chiva \& Alegre, 2009; Sun, 2003) meanwhile a learning organization can be defined as the presence of conditions that encourage learning.

Chiva \& Alegre (2009) suggested that organizational learning and job satisfaction were strongly linked. Furthermore, Egan, Yang and R. Bartlett (2004) found that learning organization was associated with job satisfaction. The study was on information technology (IT) employees in the United States. Another study conducted by Jolodar \& Jolodar (2012) concluded that there is a positive relationship between organizational learning and job satisfaction. It was also discovered that organizational leaning was positively influenced by job satisfaction, a study among academic staff in a private university in Malaysia by Moradi, Almutairi, Idrus and Emami (2013).

Therefore, these arguments help in forming the following hypothesis:

H4: Organizational leaning has positive effect on job satisfaction in Malaysian higher education sector.

\subsection{Supportive Culture}

Culture is the most vital factor towards the continuation of the participation and core values of the workers with minimum resistance.

A previous study conducted by Saha \& Kumar (2017) has obtained information from Indian public sector enterprises. Consequently, it is found in this study as the results demonstrated that supportive culture moderated the relationship between affective commitment and employee satisfaction. Furthermore, a study by Pawirosumarto et al., (2017) confirmed that organizational culture has the positive and significant impact on job satisfaction. This topic was also researched by Verma (2020) whereby in this research, Indian women employees in call centres were selected as respondents. It was revealed that supportive culture is significant to enhance employee satisfaction.

To add on, Liou, Tu, \& Chang (2012) who conducted a study to examine the mediating effect between supportive culture and job satisfaction at universities in Taiwan has found that supportive culture is directly linked to job satisfaction. Another study has found similar finding. Alsada, Al-Esmael \& Faisal (2017) confirmed that there is a significant positive relationship between supportive culture and job satisfaction.

Therefore, the following hypothesis has been formed:

H5: Supportive culture has a positive effect on job satisfaction in Malaysian higher education sector. 


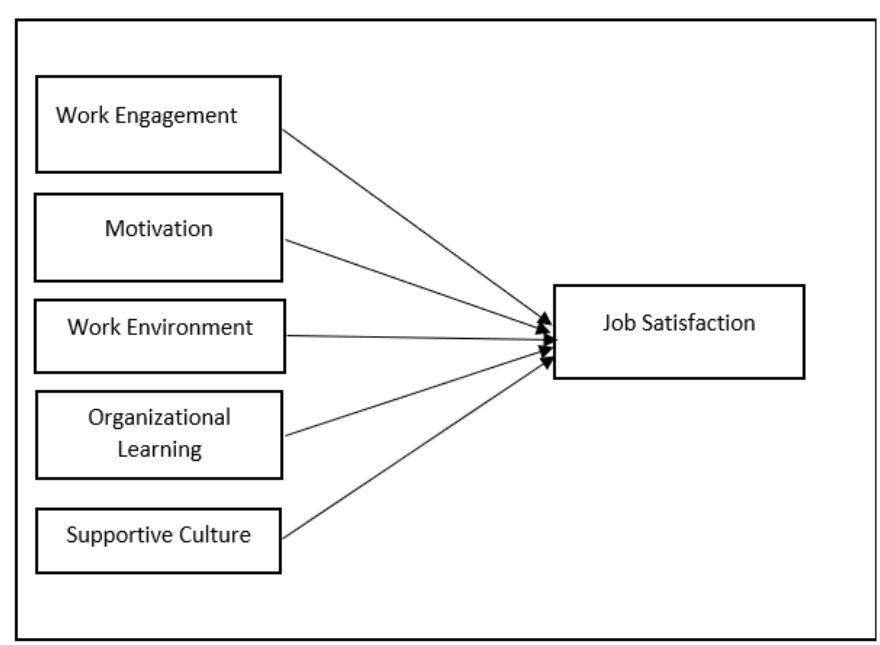

Figure 1. Research Framework of the study

\section{Methodology}

This study used quantitative approach to collect data from respondents. Specially, an online survey was used to collect the data from 169 respondents. Selection of sample size was based on recommendations by these researchers where minimum sample size should be 100 participants (Bisits-Bullen, 2014; Alshibly, 2018). By considering the rule of thumb by these researchers, thus in this study responses were collected from 169 employees in Malaysian higher education sector. This study was conducted to examine the effects of work engagement, motivation, supportive culture, work environment and organizational learning on job satisfaction. This study focused on higher education sector. The measurement scales of constructs were adapted and modified from (Hanaysha, 2016) and (Saha \& Kumar, 2018). All items were analysed using five-point Likert scale ranging " $1=$ strongly disagree" to " $5=$ strongly agree". According to Poškus (2014) by using a 5-point Likert Scale, the respondents can better understand what option he or she should choose for the answer, the researcher further added that a 5-point Likert scale is suitable for a lager study where the sample size is more than 100. The details of the construct are available in Table 1. In addition, based on the recommendation given by expert, this item has been modified to "receive supervisor's help with my personal problems". The word "supervisor" has been changed to "superior". This is to ensure that the respondents who were employees at universities can easily understand the context of the question. The data was further analysed by using a software package, the Statistical Package for the Social Sciences (SPSS).

Table 1. The Scope of variables in this study

\begin{tabular}{llll}
\hline No & Variable & & Sources \\
\hline 1$)$ & Work Engagement & 9 items & Hanaysha (2016) \\
& Motivation & 6 items & \\
& Work Environment & 5 items & \\
& Organizational Learning & 5 items & \\
\hline
\end{tabular}




\begin{tabular}{|c|c|c|c|}
\hline & Job Satisfaction & 4 items & \\
\hline 2) & Supportive culture & 8 items & $\begin{array}{l}\text { (Saha \& Kumar, } \\
\text { 2018) }\end{array}$ \\
\hline
\end{tabular}

Total 37 items

\section{Analysis of Results}

Based on the summarized demographic profiles of the respondents as shown in Table 2, it is indicated that male respondents reported for $37.3 \%$ and female respondents, $62.7 \%$. Meanwhile, for their age group most of the respondents fell within this age range $31-40$ years old reported for $58.6 \%$, followed by $41-50$ years old $(24.3 \%), 21$ - 30 years old (11.8\%) and 51 years old and above reported for 7.1\%. Remarkably, most of the respondents $(88.2 \%)$ have at least a master's degree specifically (Bachelor's, 5.9\%; Master's, $49.7 \%$ and doctorate degree, $38.5 \%$ ). Interestingly, the demographic results indicated that most of the respondents were lecturers with the percentage of $81.7 \%$, followed by officers at universities with $5.9 \%$ and supporting staff $5.3 \%$. Moreover, most of the respondents $(67.5 \%)$ were earning more than RM5000 per month, 32\% were earning more than RM7000 per month. Remarkably for area of residence, most of the respondents were from the east coast of Malaysia 38.5\% (Pahang, Terengganu \& Kelantan), followed by the central region of Malaysia consists of Selangor, Negeri Sembilan, Kuala Lumpur and Putrajaya (29.6\%), Northern Region (Perlis, Kedah \& Pulau Pinang) and Southern Region (Melaka \& Johor) with 15.4 and $16 \%$ respectively. Lastly, for years of experience at the current organization, $50.9 \%$ have more than 5 years of work experience, $18.3 \%$ of the respondents had less than 2 years of experience at the current organization, $2-3$ years (13\%) and $4-5$ years (16\%).

Table 2. Demographic statistics $(\mathrm{N}=169)$

\begin{tabular}{|c|c|c|}
\hline & Demographic & Percentage \% \\
\hline \multirow[t]{2}{*}{ Gender } & Male & 37.30 \\
\hline & Female & 62.7 \\
\hline \multirow[t]{4}{*}{ Age group } & 21-30 years & 11.8 \\
\hline & $31-40$ years & 56.8 \\
\hline & $41-50$ years & 24.3 \\
\hline & 51 and above & 7.1 \\
\hline Highest & SPM & 0.6 \\
\hline Education & Diploma & 5.3 \\
\hline \multirow[t]{3}{*}{ Level } & Bachelor's & 5.9 \\
\hline & Master's & 49.7 \\
\hline & A Doctorate Degree & 38.5 \\
\hline \multirow[t]{5}{*}{ Occupation } & A lecturer at private university & 52.1 \\
\hline & A lecturer at a public university & 29.6 \\
\hline & An officer at a private university & 4.1 \\
\hline & An officer at a public university & 1.8 \\
\hline & A supporting staff at a private university & 4.7 \\
\hline
\end{tabular}


A supporting staff at a public university

0.6

Others

\begin{tabular}{llc}
\hline Income & RM1000 - RM2000 & 3 \\
range & RM2100 - RM3000 & 5.9 \\
& RM3100 - RM4000 & 11.2 \\
& RM4100 - RM5000 & 12.4 \\
& RM5001 - RM6000 & 18.3 \\
& RM6001 - RM7000 & 17.2 \\
& More than RM7000 & 32 \\
\hline Current & Northern Region (Perlis, Kedah, Pulau & 15.4 \\
Area of & Pinang) & 16 \\
Residence & Southern Region (Melaka, Johor) & 29.6 \\
& Central Region (Selangor, Negeri Sembilan, \\
& Putrajaya, Kuala Lumpur) & 38.5 \\
& East Coast (Pahang, Terengganu, Kelantan) & 0.6 \\
\hline Years of & East Malaysia (Sarawak, Sabah) & 18.3 \\
experience at & Less than 2 years & 13 \\
the current & 4 3 years & 16 \\
organization & More than 5 years & 50.9 \\
& Others
\end{tabular}

\subsection{Reliability Assessment}

Subsequently, normality of the data was conducted using SPSS. Once the normality was attained for the data, the items were further tested for reliability using Cronbach's alpha. The reliability of the measurement items for all the variables are as indicated in Table 3, the measurement was assessed by an internal consistency check. The Cronbach Alpha from the test shows figures between $0.846-0.941$, suggesting that the instrument was stable and consistent.

Table 3. Reliability test of the measurement items

Work Engagement

Motivation

Work Environment

Organizational Learning

Supportive Culture

Job Satisfaction

Overall (total)
No of items

9

6

5

5

8

4

37 items
Cronbach's Alpha

0.846

0.894

0.894

0.941

0.937

0.923

0.972 


\subsection{Descriptive Statistics}

This section presents descriptive analysis on the variables of the study which are work engagement, motivation, work environment, organizational learning, supportive culture, and job satisfaction. The results regarding employees of higher education sector based on Malaysia's perceptions are presented in Appendix 1.

In general, the results implied that majority of respondents in this study rated most items at "agree". In addition, the mean values of the entire items for all variables exhibited score below 4.00, except work engagement but above 3 or close to 4 . Therefore, it can be concluded that all items in the study obtained a score close to agree. Appendix 1 revealed the mean score for all variables and items.

The results indicated that the highest mean for engagement construct is (Time flies when I am working $=4.44)$ followed by (I am proud on the work that I do $=4.43 ; \mathrm{I}$ am passionate about my job = 4.31). The item that exhibits the lowest mean is (I can continue working for very long period at a time $=3.74$ ). In addition, the grand mean score of 4.19 showed that participants perceived their engagement as being good.

Furthermore, for motivation "Working in this institution is interesting' had the highest mean score of 3.83, "My institution provides me with a job security" had a mean score of 3.71 and "The management of the institution show gratitude for a job well done" had the lowest mean of 3.2364 .

Meanwhile, for work environment "My workplace is very clean" scored a mean score of 4.23 and (My work environment is quiet = 3.62). Also for organizational learning, the item "Our institution encourages knowledge sharing among the staff" had the highest mean score of 3.82 , followed by "Our institution creates continuous learning opportunities" with a mean score of 3.79 and the lowest mean score was "Our institution connects the staff to the environment through various programs" with a mean score of 3.59 .

The results revealed that, "My organization is a safe place" had the highest mean score for supportive culture, followed by (People are very sociable in my organization $=3.82$ ). Meanwhile, "The management style is characterized by personal freedom" scored the lowest mean score of 3.33 .

The respondents' level of job satisfaction is also presented in Appendix 1. "I like doing the things that I do at my workplace" had the highest mean score of 4.01, "Overall, I am satisfied with my current job" had a mean score of 3.91, followed by "I am extremely glad that I chose this institution to work for, over other institutions" $=3.82$ and the lowest mean score was "I am satisfied with my earning from my current job" $=3.56$. The grand mean showed that the respondents perceived job satisfaction as good.

\subsection{Regression Summary Among Variables}

Regression summary among engagement, motivation, work environment, organizational learning, supportive culture, and job satisfaction is 0.914 ; $\mathrm{R}$ square equals 0.836 while the 
adjusted $\mathrm{R}$ square is 0.831 . The results indicated that, the five variables studied contributed $91.4 \%$ to the variation of job satisfaction.

\subsection{Results of Hypothesis Testing}

The hypotheses ( $\mathrm{H} 1, \mathrm{H} 2, \mathrm{H} 3, \mathrm{H} 4$ \& $\mathrm{H} 5)$ namely engagement, motivation, work environment, organizational learning, supportive culture on job satisfaction were tested using multiple regression analysis. According to the results in Table 5, it was indicated that the hypotheses $\mathrm{H} 1, \mathrm{H} 2, \mathrm{H} 3$ \& $\mathrm{H} 5$ were supported, engagement $(\beta=0.174 ; \mathrm{t}=3.718 ; \mathrm{p}<0.05)$, motivation $(\beta$ $=0.351 ; \mathrm{t}=5.4 ; \mathrm{p}, 0.05)$, work environment $(\beta=0.156 ; \mathrm{t}=3.497 ; \mathrm{p}<0.05)$ and supportive culture $(\beta=3.37 ; t=4.726 ; p<0.05)$. The result is consistent with Vorina et al., (2017) who found that engagement has significantly influenced job satisfaction. The result agrees with the results from Prysmakova \& Vandenabeele (2019) who reported that employees with higher levels of motivation have higher levels of job satisfaction.

In addition, the result agrees with the assertion of Kumar (2020) who found that job characteristics of (work environment) have impacted job satisfaction. To add on, a research by Sunarsi (2019) has also found that the work environment has a positive and significant impact on work satisfaction. Similarly, Akinwale \& George (2020) discovered that all variables of work environment influenced job satisfaction. Al-Hamdan, Manojlovich, \& Tanima (2017) concluded that the work environment was positively associated with job satisfaction. Additionally, a study conducted by Badrianto and Ekhsan (2020) has also found that work environment and job satisfaction leaded to positive and significant effect on employee performance. The result is also supported by Anasi (2020) who found that there is a significant linear relationship between work environment and job satisfaction.

This result also agrees with Verma (2020) where supportive culture is significant to enhance employee satisfaction. Similarly, Alsada et al., (2017) confirmed the significant positive relationship between supportive culture and job satisfaction.

However, Table 4 shows that organizational learning is not statistically a significant predictor to job satisfaction to employees of Malaysian higher education sector $(\beta=0.023 ; \mathrm{t}=0.327$; $\mathrm{p}>0.05)$.

Table 4. Results of hypotheses

\begin{tabular}{lllllll}
\hline & & $\begin{array}{l}\text { Unstandardized } \\
\text { coefficients }\end{array}$ & $\begin{array}{l}\text { Standardized } \\
\text { coefficients }\end{array}$ & & Result \\
\hline Variable & $\mathrm{B}$ & Standard Error & Beta & $\mathrm{t}$ & Sig. & \\
\hline (Constant) & -.625 & .232 & & -2.696 & .008 & \\
\hline Engagement & .289 & .078 & .174 & 3.718 & .000 & Supported \\
\hline Motivation & .348 & .064 & .351 & 5.411 & .000 & Supported \\
\hline
\end{tabular}




\begin{tabular}{lllllll}
$\begin{array}{l}\text { Work } \\
\text { environment }\end{array}$ & .172 & .049 & .156 & 3.497 & .001 & Supported \\
\hline $\begin{array}{l}\text { Organizational } \\
\text { Learning }\end{array}$ & .021 & .065 & .023 & .327 & .744 & Rejected \\
\hline $\begin{array}{l}\text { Supportive } \\
\text { Culture }\end{array}$ & .353 & .075 & .337 & 4.726 & .000 & Supported \\
\hline
\end{tabular}

\section{Note: Dependent Variable: Job Satisfaction}

\section{Conclusions and Recommendations}

This study has discovered that there is a significant relationship among engagement, motivation, work environment, supportive culture, and job satisfaction.

It is found that in this study, motivation and supportive culture are among the strongest factors that could influence job satisfaction. Hence, if these factors are taken care of by the management of universities, there will be an increase in job satisfaction and reduced turnover rate. The management of universities should implement strategies that will improve motivation level such as reward and recognition programmes and it is important to enhance supportive culture by providing psychological and social environment that could boost employees' safety, well-being and health.

In addition, the management of higher education sector needs to understand the importance of work environment for example social features, work-setting and physical environments. These elements are vital to increase job satisfaction. Furthermore, it is believed that these elements are factors that could impact the feelings, wellbeing, workplace relationships among staff, efficiency, and collaborations and most importantly their health.

Moreover, engagement is another factor that needs special attention towards job satisfaction and positive outcomes. Engagement can be defined as a constructive or positive behaviour. The management of higher education sector needs to encourage flexibility, promote work life balance, appreciate feedbacks, foster social gatherings, and clarify goals, as this study found that workers with high levels of engagement are more dedicated and satisfied with their work.

Nevertheless, among the variables studied, organizational learning is not a statistically significant predictor of job satisfaction. A study conducted by Picho (2014) indicated that there was a weak positive relationship between training \& development and job satisfaction. Besides, the researcher further explained that the weak relationship intended a small change in training was related to a small influence on job satisfaction. To add on, in this study organizational learning was found to be unimportant towards job satisfaction due to the nature of the organizations. In addition, learning opportunities, knowledge sharing, and learning-support seem to be the common practices in higher education sector, particularly 
universities. Thus, these practices are not viewed by the employees as factors that would increase job satisfaction.

This study was derived from the data set of employees in Malaysian higher education sector and it was not excused from a few limitations. This study was limited to employees of higher education in Malaysia in which future research should consider other industries or sectors.

Moreover, this study focused on Malaysian higher education sector. However, the conclusion made from this research cannot be generalized to the entire population of Malaysian higher education sector because there was only 1 respondent from the East of Malaysia (Sarawak, Sabah).

Future studies can be directed in specific organizational settings or industries for example the private universities or public universities. This is important to identify the differences and comparison among industries.

In conclusion, it is hoped that that the results of this study will be useful for other researchers especially to understand the job satisfaction among employees in higher education sector by examining other variables such as leadership styles, work load, work relationship and innovative culture might be investigated relatively to job satisfaction.

\section{References}

Abraham, S. (2012). Job satisfaction as an antecedent to employee engagement. sies Journal of Management, 8(2).

Akinwale, O. E., \& George, O. J. (2020). Work environment and job satisfaction among nurses in government tertiary hospitals in Nigeria. Rajagiri Management Journal. https://doi.org/10.1108/RAMJ-01-2020-0002

Al-Hamdan, Z., Manojlovich, M., \& Tanima, B. (2017). Jordanian nursing work environments, intent to stay, and job satisfaction. Journal of Nursing Scholarship, 49(1), 103-110. https://doi.org/10.1111/jnu.12265

Al-Sada, M., Al-Esmael, B., \& Faisal, M. N. (2017). Influence of organizational culture and leadership style on employee satisfaction, commitment and motivation in the educational sector in Qatar. EuroMed Journal of Business. https://doi.org/10.1108/EMJB-02-2016-0003

Alshibly, Haitham. (2018). Re: How large should a sample size be for multiple regression? What is the minimum? https://www.researchgate.net/post/How_large_should_a_sample_size_be_for_multiple_regre ssion_What_is_the_minimum/5a4b2f8254178d1df70cd342/citation/download.

Anasi, S. N. (2020). Perceived influence of work relationship, work load and physical work environment on job satisfaction of librarians in South-West, Nigeria. Global Knowledge, Memory and Communication. https://doi.org/10.1108/GKMC-11-2019-0135

Arnold, J., Silvester, J., Cooper, C. L., Robertson, I. T., \& Patterson, F. M. (2005). Work psychology: Understanding human behaviour in the workplace: Pearson Education. 
Badrianto, Y., \& Ekhsan, M. (2020). Effect of work environment and job satisfaction on employee performance in pt. Nesinak industries. Journal of Business Management and Accounting, 2(1), 322984.

Bisits-Bullen, Piroska. (2014) How to choose a sample size (for the statistically challenged) Retrieved from http://www.tools4dev.org/resources/how-to-choose-a-sample-size/

Castaneda, G. A., \& Scanlan, J. M. (2014). Job satisfaction in nursing: A concept analysis. Paper presented at the Nursing forum. https://doi.org/10.1111/nuf.12056

Corporate Malaysia. (2017, March 31). 78\% of Malaysians unhappy with current jobs. The Malaysian Reserve. Retrieved from https://themalaysianreserve.com/2017/03/31/78-of-malaysians-unhappy-with-current-jobs/

da Cruz Carvalho, A., Riana, I. G., \& Soares, A. d. C. Motivation on Job Satisfaction and Employee Performance.

Egan, T. M., Yang, B., \& Bartlett, K. R. (2004). The effects of organizational learning culture and job satisfaction on motivation to transfer learning and turnover intention. Human resource development quarterly, 15(3), 279-301. https://doi.org/10.1002/hrdq.1104

Fauziah, N., \& Kamaruzaman, J. (2009). Levels of Job Satisfaction amongst Malaysian Academic Staff. Journal of Asian Social Science, 5(5). https://doi.org/10.5539/ass.v5n5p122

Gitoho, S. W. (2016). Influence of Leadership Styles On Employee Job Satisfaction: A Case Study of Firms Listed In The Nairobi Securities Exchange. United States International University-Africa,

Hanaysha, J. (2016). Determinants of job satisfaction in higher education sector: Empirical insights from Malaysia. International Journal of Human Resource Studies, 6(1), 129-146. https://doi.org/10.5296/ijhrs.v6i1.9199

Hee, O. C., Ong, S. H., Ping, L. L., Kowang, T. O., \& Fei, G. C. (2019). Factors Influencing Job Satisfaction in the Higher Learning Institutions in Malaysia. International Journal of Academic Research in Business and Social Sciences, 9(2), 10-20. https://doi.org/10.6007/IJARBSS/v9-i2/5510

Jolodar, S. Y. E., \& Jolodar, S. R. E. (2012). The relationship between organizational learning capability and job satisfaction. International Journal of Human Resource Studies, 2(1), 15. https://doi.org/10.5296/ijhrs.v2i1.1242

Karanika-Murray, M., Duncan, N., Pontes, H. M., \& Griffiths, M. D. (2015). Organizational identification, work engagement, and job satisfaction. Journal of Managerial Psychology. https://doi.org/10.1108/JMP-11-2013-0359

Khan, S.-U.-R., Anjam, M., Abu Faiz, M., Khan, F., \& Khan, H. (2020). Probing the Effects of Transformational Leadership on Employees' Job Satisfaction With Interaction of Organizational Learning Culture. SAGE Open, 10(2), 2158244020930771. https://doi.org/10.1177/2158244020930771 


\section{Ml Macrothink}

International Journal of Human Resource Studies

ISSN 2162-3058

2020, Vol. 10, No. 4

Kim-Soon, N., \& Manikayasagam, G. (2015). Employee engagement and job satisfaction. Retrieved January, 14, 2017.

Kreitner, R., Kinicki, A., \& Buelens, M. (2002). Organizational behaviour: McGraw Hill London, UK.

Kumar, T. V. (2020). The influence of demographic factors and work environment on job satisfaction among police personnel: an empirical study. International Criminal Justice Review, 1057567720944599. https://doi.org/10.1177/1057567720944599

Liou, D. Y., Tu, C. C., \& Chang, S. H. (2014). Mediating effect between supportive culture and job satisfaction in administrative services at higher education institutions. Human Factors and Ergonomics in Manufacturing \& Service Industries, 24(6), 627-640. https://doi.org/10.1002/hfm.20502

Lo, M. C., \& Ramayah, T. (2011). Mentoring and job satisfaction in Malaysian SMEs. Journal of management development. https://doi.org/10.1108/02621711111126891

Maarefi, F., Zilaee, S., \& Zaman, R. (2020). The effect of organizational learning culture on job satisfaction and relationship quality with clients with mediator variable of organizational agility (A case study: Governmental hospitals in Ahwaz city. Razi Journal of Medical Sciences, 27(2), 1-9.

Marta, O. Suharnomo (2011), “Analisis pengaruh gaya kepemimpinan dan budaya organisasional terhadap kinerja organisasi: responsiveness sebagai variabel intervening". Unpublished Undergraduate Thesis, Universitas Diponegoro, Indonesia.

Mavridis, S. (2014). The Human Right to the City. https://doi.org/10.6007/MAJESS/v2-i2/1392

Meng, J., \& Berger, B. K. (2019). The impact of organizational culture and leadership performance on PR professionals' job satisfaction: Testing the joint mediating effects of engagement and trust. Public Relations Review, 45(1), 64-75. https://doi.org/10.1016/j.pubrev.2018.11.002

Moradi, E., Almutairi, D. O., Idrus, D., \& Emami, R. (2013). The influence of organizational learning culture on job satisfaction among academic staff. Journal of Global Management, 5(1), 56-66.

Ngwenya, B., \& Pelser, T. (2020). Impact of psychological capital on employee engagement, job satisfaction and employee performance in the manufacturing sector in Zimbabwe. SA Journal of Industrial Psychology, 46(1), 1-12. https://doi.org/10.4102/sajip.v46i0.1781

Nowack, K., \& Learning, E. (2011). Employee engagement, job satisfaction, retention and stress. Envisia Learning Consulting, accessed on August, 15, 2012.

Pawirosumarto, S., Sarjana, P. K., \& Gunawan, R. (2017). The effect of work environment, leadership style, and organizational culture towards job satisfaction and its implication 
towards employee performance in Parador Hotels and Resorts, Indonesia. International Journal of Law and Management. https://doi.org/10.1108/IJLMA-10-2016-0085

Picho, E. O. (2014). The Relationship between employee training and development and job satisfaction in Uganda Management Institute: an empirical study.

Poškus, Mykolas. (2014). Re: Why do you use 5 point Likert scale and not 7 point Likert scale for getting responses? Retrieved from: https://www.researchgate.net/post/Why_do_you_use_5_point_Likert_scale_and_not_7_point _Likert_scale_for_getting_responses/53eb67a7cf57d752618b4661/citation/download

Prysmakova, P., \& Vandenabeele, W. (2019). Enjoying police duties: Public service motivation and job satisfaction. Journal of police and criminal psychology, 1-14. https://doi.org/10.1007/s11896-019-09324-7

Rashidin, M. S., Javed, S., \& Liu, B. (2020). Empirical study on spirituality, employee's engagement and job satisfaction: Evidence from China. International Journal of Public Administration, 43(12), 1042-1054. https://doi.org/10.1080/01900692.2019.1665066

Saha, S., \& Kumar, S. P. (2018). Organizational culture as a moderator between affective commitment and job satisfaction. International Journal of Public Sector Management. https://doi.org/10.1108/IJPSM-03-2017-0078

Spence Laschinger, H. K., Zhu, J., \& Read, E. (2016). New nurses' perceptions of professional practice behaviours, quality of care, job satisfaction and career retention. Journal of Nursing Management, 24(5), 656-665. https://doi.org/10.1111/jonm.12370

Stefurak, T., Morgan, R., \& Johnson, R. B. (2020). The Relationship of Public Service Motivation to Job Satisfaction and Job Performance of Emergency Medical Services Professionals. Public Personnel Management, 0091026020917695. https://doi.org/10.1177/0091026020917695

Sun, H.-C. (2003). Conceptual clarifications for 'organizational learning','learning organization' and 'a learning organization'. Human resource development international, 6(2), 153-166. https://doi.org/10.1080/13678860110086465

Sunarsi, D. (2020). The Analysis of The Work Environmental and Organizational Cultural Impact on The Performance and Implication of The Work Satisfaction. Jurnal Ilmiah Ilmu Administrasi Publik, 9(2), 237-246. https://doi.org/10.26858/jiap.v9i2.11761

Tahir, N. K. M., Hussein, N., \& Rahim, A. R. A. (2020). Job Demands and Job Resources on Job Satisfaction: A Study of Staff Nurses at a General Hospital in Malaysia. International Journal of Academic Research in Business and Social Sciences, 10(13), 41-50.

Vandenabeele, W. (2014). Explaining public service motivation: The role of leadership and basic needs satisfaction. Review of Public Personnel Administration, 34(2), 153-173. https://doi.org/10.1177/0734371X14521458 


\section{Macrothink}

International Journal of Human Resource Studies

ISSN 2162-3058

2020, Vol. 10, No. 4

Verma, M. (2020). Supportive Culture: A Transformational Strategy. In Transforming Organizations Through Flexible Systems Management (pp. 177-188): Springer. https://doi.org/10.1007/978-981-13-9640-3_10

Yeh, C. M. (2013). Tourism involvement, work engagement and job satisfaction among frontline hotel employees. Annals of Tourism Research, 42, 214-239. https://doi.org/10.1016/j.annals.2013.02.002

Zahari, A. S. M., Salleh, A., Azlan, N. N. A., Syuhada, N., \& Baniamin, B. R. M. R. (2020). THE FACTORS THAT INFLUENCE JOB SATISFACTION AMONG EMPLOYEES: A CASE STUDY AT WIDAD EDUCATION SDN BHD. Journal of Global Business and Social Entrepreneurship (GBSE), 6(18).

\section{Appendix 1}

Descriptive statistics for work engagement, motivation, work environment, organizational learning, supportive culture, and job satisfaction.

\begin{tabular}{|l|l|l|l|l|l|l|r|}
\hline Statement & $\begin{array}{l}\text { Strongly } \\
\text { disagree }\end{array}$ & Disagree & Neutral & Agree & $\begin{array}{l}\text { Strongly } \\
\text { agree }\end{array}$ & Mean \\
\hline \multicolumn{5}{|c|}{ Engagement } \\
\hline $\begin{array}{l}\text { At this institution, I } \\
\text { feel energetic to do } \\
\text { my work. }\end{array}$ & $4(2.4 \%)$ & $8(4.7 \%)$ & $\begin{array}{l}30 \\
(17.8 \%)\end{array}$ & $\begin{array}{l}69 \\
(40.8 \%)\end{array}$ & $\begin{array}{l}58 \\
(34.3 \%)\end{array}$ & 3.9818 \\
\hline $\begin{array}{l}\text { At this institution, I } \\
\text { feel strong and } \\
\text { capable to do my } \\
\text { work. }\end{array}$ & $2(1.2)$ & $10(5.9)$ & $21(12.4)$ & $74(43.8)$ & $62(36.7)$ & 4.0848 \\
\hline $\begin{array}{l}\text { I can continue } \\
\text { working for very } \\
\text { long period at a } \\
\text { time. }\end{array}$ & $8(4.7)$ & $14(8.3)$ & $34(20.1)$ & $67(39.6)$ & $46(27.2)$ & 3.7455 \\
\hline $\begin{array}{l}\text { I find the work that I } \\
\text { do full of meaning } \\
\text { and purpose. }\end{array}$ & $3(1.8)$ & $4(2.4)$ & $26(15.4)$ & $72(42.6)$ & $64(37.9)$ & 4.1091 \\
\hline $\begin{array}{l}\text { I am passionate } \\
\text { about my job. }\end{array}$ & 0 & $4(2.4)$ & $24(14.2)$ & $54(32)$ & $87(51.5)$ & 4.3152 \\
\hline $\begin{array}{l}\text { I am proud on the } \\
\text { work that I do. }\end{array}$ & 0 & $1(0.6)$ & $19(11.2)$ & $55(32.5)$ & $94(55.6)$ & 4.4303 \\
\hline $\begin{array}{l}\text { To me, my job is } \\
\text { challenging. }\end{array}$ & $1(0.6)$ & $2(1.2)$ & $30(17.8)$ & $55(32.5)$ & $81(47.6)$ & 4.2545 \\
\hline $\begin{array}{l}\text { Time flies when I } \\
\text { am working. }\end{array}$ & $1(0.6)$ & $3(1.8)$ & $13(7.7)$ & $54(32)$ & $98(58)$ & 4.4424 \\
\hline I have a lot of work & $1(0.6)$ & $1(0.6)$ & $18(10.7)$ & $75(44.4)$ & $74(43.8)$ & 4.3030 \\
\hline
\end{tabular}


to do every day.

Grand mean $=4.19$

\begin{tabular}{|l|l|l|l|l|l|l|}
\hline \multicolumn{9}{|c|}{$\begin{array}{l}\text { My institution } \\
\text { provides me with a } \\
\text { job security. }\end{array}$} & $12(7.1)$ & $10(5.9)$ & $37(21.9)$ & $65(38.5)$ & $45(26.6)$ & 3.7091 \\
\hline $\begin{array}{l}\text { I receive superior's } \\
\text { help with my } \\
\text { personal problems. }\end{array}$ & $21(12.4)$ & $19(11.2)$ & $41(24.3)$ & $62(36.7)$ & $26(15.4)$ & 3.3030 \\
\hline $\begin{array}{l}\text { In my institution, I } \\
\text { receive good wages. }\end{array}$ & $10(5.9)$ & $19(11.2)$ & $38(22.5)$ & $59(34.9)$ & $43(25.4)$ & 3.6182 \\
\hline $\begin{array}{l}\text { Working in this } \\
\text { institution is } \\
\text { interesting. }\end{array}$ & $7(4.1)$ & $11(6.5)$ & $33(19.5)$ & $69(40.8)$ & $49(29)$ & 3.8303 \\
\hline $\begin{array}{l}\text { In this institution, I } \\
\text { get promotion or } \\
\text { career development } \\
\text { for good } \\
\text { achievements. }\end{array}$ & $28(16.6)$ & $12(7.1)$ & $46(27.2)$ & $54(32)$ & $29(17.2)$ & 3.2424 \\
\hline $\begin{array}{l}\text { The management of } \\
\text { the institution show } \\
\text { gratitude for a job } \\
\text { well done. }\end{array}$ & $24(14.2)$ & $20(11.8)$ & $47(27.8)$ & $46(27.2)$ & $32(18.9)$ & 3.2364 \\
\hline
\end{tabular}

Grand mean $=3.49$

\begin{tabular}{|l|l|l|l|l|l|l|}
\hline \multicolumn{9}{|c|}{ Work Environment } \\
\hline $\begin{array}{l}\text { I am satisfied with } \\
\text { the space allocated } \\
\text { for me to do my } \\
\text { work. }\end{array}$ & $11(6.5)$ & $6(3.6)$ & $35(20.7)$ & $62(36.7)$ & $55(32.5)$ & 3.8485 \\
\hline $\begin{array}{l}\text { My workplace is } \\
\text { very clean. }\end{array}$ & $1(0.6)$ & $4(2.4)$ & $18(10.7)$ & $79(46.7)$ & $67(39.6)$ & 4.2303 \\
\hline $\begin{array}{l}\text { There is adequate } \\
\text { space between me } \\
\text { and my nearest } \\
\text { colleague. }\end{array}$ & $7(4.1)$ & $10(5.9)$ & $19(11.2)$ & $74(43.8)$ & $59(34.9)$ & 3.9818 \\
\hline $\begin{array}{l}\text { My work } \\
\text { environment is } \\
\text { quiet. 15(8.9) }\end{array}$ & $17(10.1)$ & $22(13)$ & $76(45)$ & $39(23.1)$ & 3.6182 \\
\hline $\begin{array}{l}\text { Overall, my work } \\
\text { environment is } \\
\text { pleasant and }\end{array}$ & $6(3.6)$ & $11(6.5)$ & $30(17.8)$ & $70(41.4)$ & $52(30.8)$ & 3.8970 \\
\hline
\end{tabular}


visually appealing.

Grand mean $=3.92$

Organizational Learning

\begin{tabular}{|l|l|l|l|l|l|l|}
\hline $\begin{array}{l}\text { Our institution } \\
\text { creates continuous } \\
\text { learning } \\
\text { opportunities. }\end{array}$ & $13(7.7)$. & $7(4.1)$ & $33(19.5)$ & $64(37.9)$ & $52(30.8)$ & 3.7939 \\
\hline $\begin{array}{l}\text { Our institution } \\
\text { encourages } \\
\text { knowledge sharing } \\
\text { among the staff }\end{array}$ & $6(3.6)$ & $12(7.1)$ & $33(19.5)$ & $71(42)$ & $47(27.8)$ & 3.8182 \\
\hline $\begin{array}{l}\text { The leader of our } \\
\text { institution supports } \\
\text { learning at the } \\
\text { individual, team, } \\
\text { and organization } \\
\text { levels. }\end{array}$ & $12(7.1)$ & $15(8.9)$ & $38(22.5)$ & $60(35.5)$ & $44(26)$ & 3.6242 \\
\hline $\begin{array}{l}\text { Our institution } \\
\text { establishes systems } \\
\text { to capture and share } \\
\text { learning. }\end{array}$ & $8(4.7)$ & $14(8.3)$ & $34(20.1)$ & $66(39.1)$ & $47(27.8)$ & 3.7576 \\
\hline $\begin{array}{l}\text { Our institution } \\
\text { connects the staff to } \\
\text { the environment } \\
\text { through various } \\
\text { programs. }\end{array}$ & $10(5.9)$ & $22(13)$ & $33(19.5)$ & $63(37.3)$ & $41(24.3)$ & 3.5939 \\
\hline & & & & & \\
\hline
\end{tabular}

Grand mean $=3.72$

\begin{tabular}{|l|l|l|l|l|l|l|}
\hline \multicolumn{2}{|c|}{ Supportive Culture } \\
\hline $\begin{array}{l}\text { The management } \\
\text { style } \\
\text { characterized by } \\
\text { collaboration and } \\
\text { teamwork. }\end{array}$ & $13(7.70$ & $21(12.4)$ & $38(22.5)$ & $60(35.5)$ & $37(21.9)$ & 3.5030 \\
\hline $\begin{array}{l}\text { My organization is } \\
\text { relationship } \\
\text { oriented/like an } \\
\text { extended family. }\end{array}$ & $18(10.7)$ & $18(10.7)$ & $36(21.3)$ & $63(37.7)$ & $34(20.1)$ & 3.4545 \\
\hline \begin{tabular}{l} 
Encouraging new \\
\hline
\end{tabular} & $8(4.7)$ & $17(10.1)$ & $39(23.1)$ & $69(40.8)$ & $36(21.3)$ & 3.6303 \\
\hline
\end{tabular}




\begin{tabular}{|c|c|c|c|c|c|c|}
\hline $\begin{array}{lr}\text { things } & \text { and } \\
\text { prospecting } & \text { for } \\
\text { opportunities } & \text { are } \\
\text { valued. } & \end{array}$ & & & & & & \\
\hline $\begin{array}{lrr}\text { People are very } \\
\text { sociable in my } \\
\text { organization. }\end{array}$ & $5(3)$ & $6(3.6)$ & $47(27.8)$ & $67(39.6)$ & $44(26)$ & 3.8242 \\
\hline $\begin{array}{l}\text { The management } \\
\text { style is } \\
\text { characterized by } \\
\text { personal freedom. }\end{array}$ & $16(9.5)$ & $22(13)$ & $52(30.8)$ & $48(28.4)$ & $31(18.3)$ & 3.3333 \\
\hline $\begin{array}{l}\text { My organization is } \\
\text { nurturing and } \\
\text { equitable } \\
\text { employees. }\end{array}$ & $11(6.5)$ & $22(13)$ & $50(29.6)$ & $56(33.1)$ & $30(17.8)$ & 3.4121 \\
\hline $\begin{array}{l}\text { My organization is a } \\
\text { safe place. }\end{array}$ & $2(1.2)$ & $11(6.5)$ & $26(15.4)$ & $69(40.8)$ & $61(36.1)$ & 4.0364 \\
\hline $\begin{array}{l}\text { Mutual trust and } \\
\text { loyalty are the glue } \\
\text { that holds my } \\
\text { organization } \\
\text { together. }\end{array}$ & $16(9.5)$ & $13(7.7)$ & $37(21.9)$ & $68(40.2)$ & $35(20.7)$ & 3.5455 \\
\hline & & & & & & Grand mean $=3.6$ \\
\hline & & & Satisfact & & & \\
\hline $\begin{array}{l}\text { I like doing the } \\
\text { things that I do at } \\
\text { my workplace. }\end{array}$ & $5(3)$ & $6(3.6)$ & $30(17.8)$ & $69(40.8)$ & $59(34.9)$ & 4.0121 \\
\hline $\begin{array}{l}\text { I am satisfied with } \\
\text { my earning from my } \\
\text { current job. }\end{array}$ & $11(6.5)$ & $22(13)$ & $38(22.5)$ & $55(32.5)$ & $43(25.4)$ & 3.5576 \\
\hline $\begin{array}{l}\text { I am extremely glad } \\
\text { that I chose this } \\
\text { institution to work } \\
\text { for, over other } \\
\text { institutions. }\end{array}$ & $12(7.1)$ & $5(3)$ & $35(20.7)$ & $65(38.5)$ & $52(30.8)$ & 3.8182 \\
\hline $\begin{array}{lcc}\text { Overall, } & \text { I } & \text { am } \\
\text { satisfied } & \text { with } & \text { my }\end{array}$ & $3(1.8)$ & $12(7.1)$ & $31(18.3)$ & $72(42.6)$ & $51(30.2)$ & 3.9091 \\
\hline
\end{tabular}


current job.

Grand mean $=3.82$

\section{Copyright Disclaimer}

Copyright for this article is retained by the author(s), with first publication rights granted to the journal.

This is an open-access article distributed under the terms and conditions of the Creative Commons Attribution license (http://creativecommons.org/licenses/by/4.0/). 